\title{
Quality of life and associated factors for caregivers of functionally impaired elderly people
}

\author{
Luciana A. Reis ${ }^{1}$, Kleyton T. Santos ${ }^{2}$, Luana A. Reis ${ }^{3}$, \\ Nardilene P. Gomes ${ }^{3}$
}

\begin{abstract}
Background: Lifestyle changes, factors inherent to the caregiver's family and social environment, and physical and mental aspects determine a caregiver's quality of life (QOL). Objective: To evaluate the QOL and associated factors for caregivers of functionally impaired elderly people. Method: This was a cross-sectional study that analyzed data from a home-based care survey. The study sites were the homes of elderly people enrolled in Family Health Centers (Unidades de Saúde da Família) in Jequié, Bahia, Brazil. The sample consisted of 40 caregivers of functionally impaired elderly people. The instrument consisted of demographic data, health status, the Perceived Family Support Inventory, the Social Support Satisfaction Scale, and the World Health Organization Quality of Life Assessment (WHOQOL-BREF). The data were analyzed using a descriptive analysis and the chi-squared test at a 5\% significance level, performed in SPSS version 15.0. Results: An association was found between the WHOQOL-BREF physical domain and the presence of sequelae $(p=0.006)$, affective-cognitive inconsistency $(p=0.009)$, and being the primary caregiver $(p=0.002)$. The psychological domain showed an association with the presence of sequelae $(p=0.006)$, the environment domain with the presence of diseases $(p<0.001)$ and being the primary caregiver $(p=0.033)$, and the social relations domain with the presence of diseases $(p<0.001)$. Conclusion: The presence of sequelae or diseases, affective-cognitive inconsistency, and being the primary caregiver were related to decreases in their QOL.
\end{abstract}

Keywords: aging; quality of life; activities of daily living; physical therapy; rehabilitation; movement.

\section{HOW TO CITE THIS ARTICLE}

Reis LA, Santos KT, Reis LA, Gomes NP. Quality of life and associated factors of caregivers for the elderly with impaired functional capacity. Braz J Phys Ther. 2013 Mar-Apr; 17(2):146-151. http://dx.doi.org/10.1590/S1413-35552012005000078

\section{- Introduction}

The Brazilian population is aging, and even though conditions and public health policies are far from being the most adequate and affordable, aging is no longer a privilege of the few ${ }^{1}$. The aging process, when accompanied by health problems, often functionally impairs the elderly, making them increasingly dependent on others to perform activities such as dressing, feeding, and bathing themselves, as well as administering medications and other tasks, and these obligations are borne by third parties ${ }^{2}$.

The caregiver's role is to be responsible for the care of and full attention to the elderly. However, tasks are assigned to the caregiver that, in most cases, are not accompanied by appropriate instructions. This obstacle directly affects their quality of life (QOL), including health problems ranging from mental to physical overload and body pain ${ }^{3}$. The load endured by the caregiver makes this person deserving of as much attention as the elderly who are under their care.
The disabled elderly person's caregiver is usually a family member who devotes much of his or her time and effort to their care. That lifestyle change, together with factors inherent to the family and social environment, as much the caregiver's as the elderly person's, and physical and mental aspects, combine to determine the caregiver's $\mathrm{QOL}^{4}$. Caregivers of elderly are often under-skilled because their training courses are still focused on concepts and theories from a biological perspective. Therefore, the implementation of measures focusing on the caregiver is critical to prepare them adequately by teaching them appropriate practices, which would benefit the lives of those who provide care and those who receive the care ${ }^{5}$.

Given the above and considering that the caregivers' lack of preparation is difficult to resolve in the short term, the caregivers' lifestyle, QOL status, and physical and mental aspects must be

\footnotetext{
${ }^{1}$ Faculdade Independente do Nordeste, Universidade Estadual do Sudoeste da Bahia (UESB), Vitória da Conquista, BA, Brazil

${ }^{2}$ Universidade Estadual do Sudoeste da Bahia, Jequié, BA, Brazil

${ }^{3}$ Universidade Federal da Bahia (UFBA), Salvador, BA, Brazil

Received: 05/22/2012 Revised: 10/04/2012 Accepted: 11/21/2012
} 
known ${ }^{6,7}$ so that we can understand the factors that affect their health status. This knowledge would enable rehabilitation science professionals to adopt preventive and curative multidisciplinary healthcare measures based on those data. The aim of this study is to evaluate the QOL and associated factors for the caregivers of functionally impaired elderly people to help plan and adopt multidisciplinary measures for improving the caregivers' QOL.

\section{- Method}

This was a cross-sectional study that analyzed data from a home-based care survey, termed "Relationship between family caregivers' training and the quality of care provided to functionally impaired elderly people" ("Relação entre capacitação dos cuidadores familiares e a qualidade da assistência prestada ao idoso com comprometimento da capacidade funcional"). The study sites were the homes of the elderly enrolled in the Family Healthcare Centers (Unidades de Saúde da Família) within the area included in the Jequiezinho neighborhood, in the municipality of Jequié, located in the southwest region of the state of Bahia, Brazil. According to the Brazilian Institute of Geography and Statistics census, in 2000, there were 147,202 inhabitants in the municipality of Jequié, with 71,899 men and 75,305 women; 14,085 of these inhabitants $(9.6 \%)$ are over 60 years of age.

The sample of the present study consisted of 40 caregivers of functionally impaired elderly people. This research study was approved by the Ethics Committee for Human Research, Southwest Bahia State University (Comitê de Ética em Pesquisa com Seres Humanos, da Universidade Estadual do Sudoeste da Bahia) (Opinion No. 189/2008). All study subjects freely signed the informed consent form.

The study instrument consisted of sociodemographic data (gender, age group, education, marital status, relationship to the patient, and status as the primary or non-primary caregiver) and health conditions (presence and type of health problems and sequelae, completion, and type of treatment). Family support was examined using the Perceived Family Support Inventory (PFSI) ${ }^{8}$, which assesses issues such as family adaptation, autonomy, and affective-cognitive consistency of the elderly living at home. Social support ${ }^{9}$ was assessed using the Social Support Satisfaction Scale (SSSS). QOL was evaluated using the World Health Organization Quality of Life Assessment (WHOQOL-BREF) ${ }^{10}$.
PFSI was validated for Brazil by Baptista $(2005)^{8}$ and consists of 42 items, divided into three dimensions. Its first dimension is termed affective-cognitive consistency, which involves questions regarding the expression of affection between members, whether verbal or not, as well as concern, sympathy, care, consistency of behavior, and problem-solving skills. The second dimension is termed family adaptation, and it scores questions regarding negative feelings towards the family unit, including anger, isolation, exclusion, and lack of understanding, indicating the absence of adaptation in the group. The last dimension is autonomy, wherein relationships of trust, freedom, and privacy among members are evaluated.

$\operatorname{SSSS}^{9}$ is a self-report questionnaire validated for Brazil, which enables the assessment of satisfaction with social support through its four dimensions. The first dimension, satisfaction with friends, measures the satisfaction with friendships/friends and includes five items. The second, termed closeness, measures the perceived existence of close social support and consists of four items. The third factor, termed satisfaction with family, measures the satisfaction with the social support of the existing family and is comprised of three items. The fourth factor, termed social activities, measures the satisfaction with social activities the subject participates in and is comprised of three items.

The WHOQOL-BREF ${ }^{10}$ is a self-administered questionnaire validated for Brazil, comprising 24 items divided into six domains: sensory function; autonomy; death and dying; past, present, and future activities; social anticipation; and closeness. The sensory function domain evaluates the sensory functioning (sight, hearing, touch, smell, and taste) and the impact of losing those sensory abilities on QOL. The domain autonomy domain refers to the ability of the subject to live independently and make their own decisions. The past, present, and future activities domain describes the subject's satisfaction with their achievements in life and their desires. Social participation outlines the participation in daily activities, especially in the community. The death and dying domain relates to concerns, anxieties, and fears about death. Closeness assesses the ability to build personal and close relationships.

The functional capacity of the elderly was assessed using the Barthel Index (used for assessing the basic activities of daily living $)^{10}$ and the Lawton Scale (used for assessing the instrumental activities of daily living $)^{10}$. The application of these scales showed that all the elderly evaluated (100\%) had difficulty in 
performing one of the activities of daily living, $62.5 \%$ were rated mildly dependent in the basic activities, and $52.5 \%$ were rated partly dependent in terms of the instrumental activities.

The data were analyzed using the statistical software SPSS, version 15.0. We performed descriptive analyses to characterize the sociodemographic and health data, PFSI and SSSS dimensions, and QOL domains, and we used Pearson's chi-squared test to assess the study variables associated with the caregivers' QOL domains. The significance level was $5 \%(p<0.05)$.

\section{Results}

Most caregivers evaluated were women (85\%). Many lived with their spouse or partner $(42.5 \%)$, had between 5 and 8 years of education (30\%), had a paternal kinship with the elderly patient (47.5\%), was the primary caregiver (80\%), and had health problems $(82.5 \%)$, the most frequent of which were hypertension associated with osteoporosis $(17.5 \%)$, hypertension (12.5\%), arthritis associated with migraine $(10 \%)$, and hypertension associated with lower back pain $(7.5 \%)$ (Table 1$)$.

The QOL of caregivers of functionally impaired elderly people was most compromised in the physical (65.08 points) and environment WHOQOL-BREF domains (60.93 points) (Table 2).

Regarding the perception of family support, caregivers showed greater impairment in affectivecognitive consistency (31.13 points). The caregivers' greatest impairment in SSSS was in satisfaction with friends (18.83 points), closeness (12.78 points), and social assistance ( 8 points) factors (Table 3 ).

The score of the WHOQOL-BREF Physical domain was significantly associated with the presence of sequelae $(p=0.006)$, affective-cognitive consistency $(p=0.009)$, and being the primary caregiver $(p=0.002)$, as determined by Pearson's chi-squared test. The psychological QOL domain was significantly associated with the presence of sequelae ( $p=0.006$ ), the environment domain with the presence of disease $(p<0.001)$ and being the primary caregiver $(p=0.033)$, and the social relations domain with the presence of disease $(p<0.001)$.

\section{- Discussion}

The present study shows that caring for the elderly is almost exclusively borne by women, corroborating the results of a study conducted in the municipality of São Paulo ${ }^{4}$. That finding is interlaced with cultural factors and the conventionalities of society, wherein women have caregiver role and are linked to aspects of life and care ${ }^{11}$, whereas Martins et al. ${ }^{12}$ offered the simpler explanation that the female population predominates in most countries.

A rather worrying finding from the present study was that only $15 \%$ of the population had more than nine years of education. Such a low level of education is correlated with less access to information. This condition, combined with the lack of guidelines, not only compromises the health of the elderly being cared for but also the caregiver's own health ${ }^{3}$. In

Table 1. Profile of caregivers of older adults with impaired functional capacity. Jequié, Bahia, Brazil, 2012.

\begin{tabular}{|c|c|c|}
\hline Variable & $\mathbf{n}$ & $\%$ \\
\hline $\begin{array}{l}\text { Sex } \\
\text { Female }\end{array}$ & 34 & 85.0 \\
\hline Male & 6 & 15.0 \\
\hline \multicolumn{3}{|l|}{ Marital status } \\
\hline Single & 13 & 32.5 \\
\hline Living with spouse or partner & 17 & 42.5 \\
\hline Separated, legally separated, or divorced & 10 & 25.0 \\
\hline \multicolumn{3}{|l|}{ Education } \\
\hline Illiterate & 11 & 27.5 \\
\hline Can read/write informally & 6 & 15.0 \\
\hline 1 to 4 years & 5 & 12.5 \\
\hline 5 to 8 years & 12 & 30.0 \\
\hline 9 to 12 years & 4 & 10.0 \\
\hline 13 or more years & 2 & 5.0 \\
\hline \multicolumn{3}{|l|}{ Degree of kinship } \\
\hline Son & 19 & 47.5 \\
\hline Caregiver & 4 & 10.0 \\
\hline Sister & 4 & 10.0 \\
\hline Spouse & 7 & 17.5 \\
\hline Niece & 3 & 7.5 \\
\hline Granddaughter & 2 & 5.0 \\
\hline Daughter-in-law & 1 & 2.5 \\
\hline \multicolumn{3}{|l|}{ Primary caregiver } \\
\hline Yes & 32 & 80.0 \\
\hline No & 6 & 15.0 \\
\hline \multicolumn{3}{|l|}{ Presence of health problems } \\
\hline No & 7 & 17.5 \\
\hline Yes & 33 & 82.5 \\
\hline Total & 40 & 100.0 \\
\hline
\end{tabular}


Table 2. Scores on the domains of whoqol-bref. jequié, Bahia, Brazil, 2012.

\begin{tabular}{lcccc}
\hline \multicolumn{1}{c}{ Domain } & $\mathbf{n}$ & Mean & Standard deviation & 95\% CI \\
Physical & 40 & 65.08 & 15.67 & 60.08 \\
Psychological & 40 & 74.37 & 18.38 & 68.49 \\
Social Relations & 40 & 72.70 & 19.97 & 66.32 \\
Environment & 40 & 60.93 & 13.31 & 56.68 \\
\hline
\end{tabular}

Table 3. Scores on the Perceived Family Support Inventory and the Social Support Satisfaction Scale dimensions. Jequié, Bahia, Brazil, 2012.

\begin{tabular}{lcccc}
\hline \multicolumn{1}{c}{ Dimension } & n & Mean & Standard deviation & 95\% CI \\
Perceived Family Support Inventory & & & 7.88 & 28.6 \\
Affective-Cognitive Consistency & 40 & 31.13 & 3.69 & 3.06 \\
Family Adaptation & 40 & 4.25 & 1.42 & 14.44 \\
Autonomy & 40 & 14.9 & & 17.26 \\
Social Support Satisfaction Scale & & & 11.34 \\
Satisfaction with Friends & 40 & 18.33 & 4.46 & 13.69 \\
Closeness & 40 & 12.78 & 1.34 & 6.91 \\
Satisfaction with Family & 40 & 14.13 & 3.4 & \\
Social Support & 40 & 8.00 & & \\
\hline
\end{tabular}

another study, caregivers with less than eight years of education had lower scores of general health status ${ }^{4}$.

This study detected a high prevalence of health problems in caregivers. In a previous analysis of 40 caregivers of elderly people, the burden placed on them directly affected their QOL and health status, as they often suffered from hypertension and cardiovascular, musculoskeletal, and mental health problems ${ }^{13,14}$. This association is quite worrisome, especially considering that these are the main pathologies related to morbidity and mortality in the general population.

The health risk is even greater considering that nearly all caregivers were related to the elderly patients in the present study population, that is, they were informal caregivers. Informal caregivers are exposed to a variety of stressors, including the burden of tasks and diseases resulting from the job demands and the characteristics of the elderly ${ }^{15}$. The caregivers' psychological involvement is also higher because they are related to the patients, and the deterioration of the health condition of their elderly charges results in the decline of their own health ${ }^{16}$.

The QOL assessment showed that the physical and environment domains were the most impaired, while the psychological was the least affected. This result is similar to previous findings in that it identifies the physical domain as one of the most affected, especially with the presence of body aches, fatigue, and musculoskeletal problems ${ }^{2,14}$, but differs from others that reported large-scale psychological impairment ${ }^{17}$.

In a study conducted in Portugal, when the elderly were asked to compare their current health status to that of five years prior, nearly half of the participants reported having worsened health ${ }^{14}$. Several factors contributed to that decline, including strenuous and repetitive activities, the burden of tasks, and the need to wake up at night. However, the greatest difficulty in most cases is the stubbornness and resistance of the elderly to perform some functions ${ }^{15}$.

Another factor that seems to affect the QOL of caregivers directly is that they start living the life of their elderly charges, reducing their social support network of friends and relatives given the lack of time and opportunity for recreation, work outside the home, and changes in the family routine ${ }^{18}$. This finding is supported by the results of the present study, wherein the main impairments in SSSS were in the satisfaction with friends and closeness domains.

A network of social support will mainly affect the improvement of the caregiver's emotional aspects, which, in turn, may affect all other areas. This support ranges from the demonstration of confidence to the 
guidelines received by professionals ${ }^{18}$. Caregivers who maintain or receive some social support notably have better scores in the social relations domain ${ }^{19}$. Providing support to caregivers contributes to relief work and stress situations they are experiencing ${ }^{20}$. Family also has a key role in QOL preservation, although family ties are not always sustained because of changes at the time the subject becomes the caregiver $^{20}$.

In this study, the presence of sequelae showed statistically significant effects on both the physical and psychological domains of WHOQOL-BREF, and the presence of disease showed statistically significant effects on the environment and social relations domains. Those findings are corroborated in the literature, which shows that caregivers who work overtime and experience wear and fatigue show anxiety, depression, and somatization ${ }^{16}$. Therefore, the relationship becomes bidirectional, with sequelae and diseases impairing the QOL domains and the low QOL affecting the disease involvement and generating sequelae.

Lower scores in the physical and environment domains were also related to the caregiver's status as primary caregiver. These caregivers dedicate themselves full-time to the elderly, often with no time remaining to take care of their own health ${ }^{21}$. One study found that the presence of pain and physical limitations was the main caregivers' complaint ${ }^{13}$. The adaptations made to the living space for the comfort of the elderly dependent are not always helpful adaptations to the caregiver's demands ${ }^{16}$. Activities requiring physical space are those that bring the greatest challenges for caregivers ${ }^{15}$.

A finding deserving of close attention is the relationship between the physical domain of QOL and the affective-cognitive consistency dimension of PFSI. Caregivers are constantly facing opposing feelings, including love and anger, attachment and abandonment, and patience and impatience. This change in behavior is aggravated by physical wear, and abuse of and violence towards the elderly often arise in such situations ${ }^{5,15,21}$.

Considering the results found in this and other studies, the QOL of caregivers of elderly people is often quite compromised, especially in the physical domain and in the primary caregiver. The presence of sequelae and diseases is also noticeably related to the decrease in QOL aspects.

Thus, the need for improved monitoring of caregivers of the elderly Brazilian population is clear. This monitoring should be provided by a multidisciplinary team, especially including a physical therapist, who would strive toward prevention, education, ergonomics, rehabilitation, adequate management practices for the needy elderly, and the emotional aspects of coexistence. These interventions will greatly improve the QOL and health not only of the caregiver but also of the person being cared for. Another interesting strategy is to encourage the formation of groups of informal caregivers, led by healthcare professionals with the aim of promoting knowledge, exchanging experiences, collaborating on work activities, and discussing the best strategies for caregiving ${ }^{6}$.

\section{Acknowledgements}

We thank Bahia State Research Foundation (Fundação de Amparo a Pesquisa do Estado da Bahia, FAPESB).

\section{References}

1. Sampaio RF, Augusto VG. Aging and work: a challenge for the rehabilitation schedule. Rev Bras Fisioter. 2012;16(2):94-101. http://dx.doi.org/10.1590/ S1413-35552012000200003

2. Zem-Mascarenhas SH, Barros ACT, Carvalho SJC. Um olhar atento sobre a prática do cuidador familiar. Rev Min Enf. 2006;10(2):132-37.

3. Mendes GD, Miranda SM, Borges MMMC. Saúde do cuidador de idosos: um desafio para o cuidado. Rev Enferm Integrada. 2010;3(1):408-21

4. Ferreira CG, Alexandre TS, Lemos ND. Fatores associados à qualidade de vida de cuidadores de idosos em assistência domiciliar. Saúde Soc. 2011;20(2):398-409. http://dx.doi. org/10.1590/S0104-12902011000200012

5. Moreira MD, Caldas CP. A importância do cuidador no contexto da saúde do idoso. Esc Anna Nery R Enferm. 2007;11(3):520-5. http://dx.doi.org/10.1590/ S1414-81452007000300019

6. Rocha Júnior PR, Corrente JE, Hattor $\mathrm{CH}$, Oliveira IM, Zancheta D, Gallo CG, et al. Efeito da capacitação dos cuidadores informais sobre a qualidade de vida de idosos com déficit de autocuidado. Ciênc Saúde Coletiva. 2011;16(7):3131-38. PMid:21808901.

7. Instituto Brasileiro de Geografia e Estatística - IBGE. Censo 2000. [cited 2007 Mar 20]. Available from: http:// www.ibge.gov.br/ cidadesat/index $2 . \mathrm{html}$.

8. Baptista MN. Desenvolvimento do Inventário de Percepção de Suporte Familiar (IPSF): estudos psicométricos preliminares. Psico-USF. 2005;10(1):11-9.

9. Stamm M, Mioto RCT. Família e cuidado: uma leitura para além do obvio. Cienc Cuid Saúde. 2003;2(2):161-8.

10. Chikude T, Fujiki EM, Honda EK, Ono NK, Milani C. Avaliação da qualidade de vida dos pacientes idosos com fratura de colo de fêmur tratados cirurgicamente pela artroplastia parcial do quadril. Acta Ortop 
Bras. 2007;15(4):32-40. http://dx.doi.org/10.1590/ S1413-78522007000400004

11. Sena RRD, Silva KL, Rates HF, Vivas KL, Queiroz CM, Barreto FO. O cotidiano do cuidador no domicílio: desafios do bem fazer solitário. Cogitare Enferm. 2006;11(2):124-32.

12. Martins JJ, Albuquerque GL, Nascimento ERP, Barra DCC, Souza WGA, Pacheco WNS. Necessidades de educação em saúde dos cuidadores de pessoas idosas. Texto Contexto Enferm. 2007;16(2):254-62. http://dx.doi. org/10.1590/S0104-07072007000200007

13. Trentino AC, Damasceno EP, Vieira LML. Avaliação do nível de estresse e da qualidade de vida dos cuidadores de pacientes idosos internados no hospital de retaguarda. Omnia Saúde. 2009;6(1):14-26.

14. Pimenta GMF, Costa MADMC, Gonçalves LHT, Alvarez AM. Profile of the caregiver of dependent elderly family members in a home environment in the City of Porto, Portugal. Rev Esc Enferm USP. 2009;43(3):606-11.

15. Rocha MPF, Vieira MA, Sena RR. Desvelando o cotidiano dos cuidadores informais de idosos. Rev Bras Enferm. 2008;61(6):801-8. http://dx.doi.org/10.1590/ S0034-71672008000600002

16. Silveira TM, Caldas CP, Carneiro TF. Cuidando de idosos altamente dependentes na comunidade: um estudo sobre cuidadores familiares principais. Cad Saude Publica. 2006;22(8):1629-38. http://dx.doi.org/10.1590/ S0102-311X2006000800011

17. Rodrigues SLA, Watanabe HAW, Derntl AM. A saúde de idosos que cuidam de idosos. Rev Esc Enferm
USP. 2006;40(4):493- 500. http://dx.doi.org/10.1590/ S0080-62342006000400007

18. Amendola F, Oliveira MAC, Alvarenga MRM. Influence of social support on the quality of life of family caregivers while caring for people with dependence. Rev Esc Enferm USP. 2011;45(4):884-9. PMid:21876888. http://dx.doi. org/10.1590/S0080-62342011000400013

19. Guedea MTD, Damacena FA, Carbajal MMM, Marcobich PO, Hernández GA, Lizárraga LV, et al. Necessidade de apoio social em cuidadores de familiares idosos mexicanos. Psicol Soc. 2009;21(2):242-49. http://dx.doi. org/10.1590/S0102-71822009000200011

20. Rodríguez-Sánchez E, Pérez-Peñaranda A, LosadaBaltar A, Pérez-Arechaederra, Gómez-Marcos MA, Patino-Alonso MC, et al. Relationships between quality of life and family function in caregiver. BMC Fam Pract. 2011;12:1-7. PMid:21496270 PMCid:3089776. http://dx.doi.org/10.1186/1471-2296-12-19

21. Nascimento LC, Moraes ER, Silva JC, Veloso LC, Vale ARMC. Cuidar de idosos: conhecimento disponível na base de dados LILACS. Rev Bras Enferm. 2008;61(4):514-7. http://dx.doi.org/10.1590/S0034-71672008000400019

\section{Correspence}

\section{Luciana Araújo dos Reis}

Av. Olívia Flores, 810

Ed. Magestic, apto. 404, Candeias

CEP 45000-000, Vitória da Conquista, BA, Brazil

e-mail: lucianauesb@yahoo.com.br 